\title{
Microbial Community Analysis of Rhizosphere of Healthy and Wilted Pepper (Capsicum Annuum L.) in An Organic Farming System
}

\section{Román González-Escobedo}

Universidad Autónoma de Chihuahua

Laila N. Muñoz-Castellanos

Universidad Autónoma de Chihuahua

Zilia Y. Muñoz-Ramirez

Instituto Politécnico Nacional

César Guigón López

Universidad Autónoma de Chihuahua

Graciela Dolores Avila-Quezada ( $\nabla$ gavilaq@gmail.com )

Universidad Autonoma de Chihuahua https://orcid.org/0000-0002-9633-152X

\section{Research Article}

Keywords: microbiome, metagenomic, rhizosphere, chili pepper, bacteria, fungi.

Posted Date: June 4th, 2021

DOl: https://doi.org/10.21203/rs.3.rs-575849/v1

License: (c) (i) This work is licensed under a Creative Commons Attribution 4.0 International License. Read Full License 


\section{Abstract}

Rhizosphere microorganisms play an important role in the growth and health of plants. Around the world, diverse soil-borne pathogens attack Capsicum annuum causing significant damage and economic losses; however, very little is known about how rhizosphere microbial communities are altered by infestation with root pathogens. This work aimed to determine whether the diversity and structure of microbial communities in the rhizosphere soil of $C$. annuum plants is significantly changed by wilt disease. We used 16S rRNA for bacteria and the internal transcribed spacer region for fungi, to characterize the rhizosphere microbiomes of healthy and wilted plants. The most abundant bacterial phyla were Proteobacteria and Gemmatimonadetes, while the most abundant fungal phyla were Ascomycota and Mucoromycota. The bacterial a-diversity did not show significant differences in richness and diversity, but did show a significant difference in evenness and dominance of species. Rare taxa were present in both healthy and wilted conditions with relative abundances $<1 \%$. In the fungi, all evaluated estimators showed a significant reduction in the wilted condition. The $\beta$-diversity showed significant differences in the structure of bacterial and fungal communities, which were segregated according to plant health condition. The differential abundance analysis did not show significant results in the bacterial communities; however, in the fungal communities, Rhizopus, Thanatephorus, Curvularia, Fusarium, Cladosporium, and Alternaria were more abundant in the rhizosphere of wilted than healthy plants. Species from these genera have been previously reported as phytopathogens of several plants, including in reports on individual species as disease agents in $C$. annuum.

\section{Introduction}

The soil microbiota plays an essential role in decomposing organic matter, cycling nutrients and fertilizing the soil, as well as in interactions with plants to provide protection against pathogens [6], water stress [41], and the assimilation of minerals such as phosphorus [10]. The rhizosphere is a zone of high biological activity, with many interactions between plants and rhizobacteria that enhance plant growth and biological control activity [26]. This relationship provides the plants with protection against pathogens, by altering their microbiome to a beneficial community [6]. Beneficial organisms that have been found in the rhizosphere include plant growth-promoting rhizobacteria (PGPR), nitrogen-fixing bacteria, and mycorrhizal fungi [39, 44], as well as Trichoderma spp., Metarhizium spp., Beauveria spp. $[23,47]$, and others. Many genera of PGPR have been reported to interact with plants, including Agrobacterium, Azotobacter, Azospirillum, Bacillus, Caulobacter, Chromobacterium, Erwinia, Flavobacterium, Micrococcus, Pseudomonas, and Serratia, as well as nitrogen-fixing endophytic rhizobacterial genera, such as Bradyrhizobium, Allorhizobium, Mesorhizobium, and Azorhizobium [15, 25-27]. Actinomycetes are one of the major components of rhizobacteria that are beneficial to plants, and include Streptomyces, Streptosporangium, Thermobifida, and Micromonospora.

Chili pepper (Capsicum annuum L.) is one of the most important crops grown in Mexico. It can be used as a spice, a vegetable of high nutritional value, a food colorant, in addition to having pharmaceutical applications [3]. Diverse pathogens such as Phytophthora capsici [17], Verticillium dahliae [54, 69], 
Fusarium oxysporum [68, 69], Fusarium lateritium [67], Fusarium solani [64], Rhizoctonia solani, Pythium spp. [69], Sclerotinia sclerotiorum, Sclerotium rolfsii [64], and Macrophomina sp. [67], trigger root-rot as well as wilting, stem-, leaf-, and fruit-blight, which cause significant damage to chili pepper crops, and thus, economic losses in production in Mexico [11, 22, 53, 57]. Previous studies have reported that beneficial microbes, such as PGPR and beneficial fungi $[31,32,38]$, can be recruited by host plants to counteract pathogen infection [14].

For several years, the interactions between plants and pathogens have been studied under the concept of an individual plant-microorganism relationship, an approach that ignores the complexity of such interactions and the involvement of many other groups of microorganisms that affect the outcome of infection. Aside from these studies of diseasecausing agents and biocontrol microorganisms, to our knowledge few studies using Next-Generation Sequencing have been carried out to identify communities

of microorganisms in the rhizosphere of Capsicum annuum L. Metagenomic analysis and comparison of plant-associated microbiomes have led to the successful identification of microorganisms that are either beneficial or pathogenic to plants. The objective of this study was to characterize and compare the diversity and structure of the rhizosphere microbiome in healthy and wilted $C$. annuum $L$. plants through 16S rRNA and ITS region amplicon sequencing by Illumina MiSEq. This study has deepened our understanding of the changes in microbial communities and the presence of beneficial and pathogenic members associated with the rhizosphere of $C$. annuum plants.

\section{Methods}

\section{Site description and samples collection}

We collected soil samples from organic farm plots under $C$. annuum cultivation, containing healthy and wilt-diseased plants, at a location in the municipality of Camargo, in Chihuahua State, Mexico $\left(27^{\circ} 39^{\prime} 75^{\prime \prime} \mathrm{N}, 105^{\circ} 07^{\prime} 84^{\prime \prime} \mathrm{W} ; 1240 \mathrm{masl}\right)$ in June 2020 . We took samples randomly with three replicates of soils from plants in each health condition (healthy or wilted). We selected rhizosphere soil samples from three plants at the fruiting stage ( $40 \mathrm{~cm}$ tall) in each condition: first, we collected rhizosphere soils from wilt-diseased plants (wilted condition) $40 \mathrm{~m}$ apart from each other; then, we collected rhizosphere soil samples from healthy plants (healthy condition) at a distance of $100 \mathrm{~m}$ from the wilted plants, to complete a total of three replicates for each condition. We placed the rhizosphere soil samples individually in sterile bags and stored them on ice for transport to the laboratory, where they were then stored until processing.

Rhizosphere samples were numbered as follows: BJS1, BJS2, and BJS3, as well as HJS1, HJS2, and HJS3 were bacterial and fungal soil samples, respectively, from healthy $C$. annuum plants; and BJE1, BJE2, and BJE3, as well as HJE1, HJE2, and HJE3 were bacterial and fungal soil samples, respectively, from wilted $C$. annuum plants. 


\section{Metagenomic Dna Extraction, Library Preparation, And Sequencing}

We extracted the metagenomic DNA individually from each soil sample using a ZymoBIOMICS ${ }^{\text {TM }}$ DNA Miniprep Kit (Zymo Research, Irvine, CA, U.S.A.) following the manufacturer's instructions. We quantified the quality and integrity of the DNA using a NanoDrop 2000c spectrophotometer (Thermo Scientific, Wilmington, DE) based on its A260/280 ratio, and observed it in a $1.0 \%$ agarose gel electrophoresis. The 16S rRNA gene (V3-V4 region) and ITS region (ITS) libraries obtained from bacterial and fungal communities, respectively, were amplified and sequenced using paired-end $2 \times 250$ bp on an Illumina MiSeq sequencer (Illumina Inc., San Diego, CA, U.S.A.) at Novogene, Beijing, China.

\section{Bioinformatic Analysis}

We merged demultiplexed raw paired-end sequences in fastq format using FLASH v1.2.11 with default settings [40]. We quality-filtered, trimmed, and de-noised the merged sequences using DADA2 [8] in Quantitative Insights Into Microbial Ecology (QIIME2 v2020.2) [7] to obtain representative amplicon sequence variants (ASV). After completing the qualityfiltering step, we did multiple sequence alignment and phylogenetic reconstruction using MAFFT and FastTree, respectively, to generate a rooted phylogenetic tree[33, 51]. We extracted representative sequences and their abundances by feature-table, and did the taxonomy assignment with a pre-trained Naïve Bayes classifier using the Greengenes (v.13_8) database for bacteria, and the UNITE (v.8_99) database for fungi.

In order to analyze the $\alpha$ - and $\beta$-diversity of bacterial and fungal communities and conduct related statistical tests, we rarefied the samples at the depth of the library with the lowest number of reads, and calculated the metrics using the R package vegan. To explore a-diversity within these communities in both healthy and wilted conditions, we estimated species richness using Cha01, species diversity with the Shannon index, dominance with the Simpson index, and the species evenness index; using the KruskalWallis test these were considered statistically significant at $p$ values $<0.05$.

To investigate differences in bacterial and fungal communities' composition between healthy and wilted conditions, we performed a principal coordinate analysis (PCOA) based on Bray-Curtis distances and unweighted UniFrac distances. We then used an analysis of similarities (ANOSIM) to test for significant differences among bacterial and fungal communities. Venn diagrams were plotted using the feature-table at the genus level with the R package ggvenn. Finally, we did a differential abundance test using ALDEx2 [20] to identify bacterial and fungal taxa that were significantly different across the rhizosphere samples from both healthy and wilted conditions at the genus level. We depicted the results as a volcano plot and bar plots using the R package ggplot2.

\section{Results}




\section{Sequencing results}

We obtained a total of $1,218,821$ and 1,154,540 raw sequences from bacteria and fungi, respectively. After applying the quality control criteria, we retained a total of 857,743 and $1,040,617$ high-quality sequences from bacteria and fungi, respectively. To conduct subsequent analyses, we rarefied the samples to the lowest number of reads per library; in the case of bacteria, we homogenized all samples to 134,116 reads (Supplementary Fig. 1a); and for fungi, we homogenized the samples to 162,089 reads (Supplementary Fig. 1b).

\section{Microbial Community Composition}

A total of 43 distinct phyla, 241 families, and 458 bacterial genera were identified. At the phylum level, Proteobacteria was the most abundant with $>36 \%$ of relative abundance, followed by Gemmatimonadetes (20.34\%), Actinobacteria (11.51\%), Bacteroidetes (9.71\%), Acidobacteria (7.72\%), Firmicutes (4.24\%), Chloroflexi (4.11\%), Nitrospirae (1.36\%), and Verrucomicrobia (1.16\%); the remaining 34 phyla had relative abundance $<1.00 \%$. At the family level, Cytophagaceae was the most abundant (4\%), followed by Sphingomonadaceae (3.73\%), Xanthomonadaceae (2.83\%), Rhodospirillaceae (2.61\%), Hyphomicrobiaceae (1.66\%), Bacillaceae (1.32\%), Chitinophagaceae (1.15\%), and Bradyrhizobiaceae $(1.13 \%)$; the remaining families represented $<1.00 \%$. At the genus level, a high number of bacteria were found (458 genera), the relative abundance distribution was very homogeneous; in fact, the most abundant genera were Kaistobacter, Bacillus, Rubrobacter, Streptomyces, Balneimonas, Nitrospira, and Salinimicrobium, with values ranging from $5.67-3.17 \%$ of relative abundance; 16 genera ranged from 2$1 \%$, and the remaining 435 genera represented values $<1.00 \%$ of relative abundance (Fig. 1 a shows the 20 most abundant bacterial genera).

Among the fungi, 13 distinct phyla, 132 families, and 257 genera were identified. The phylum Ascomycota was the most abundant taxonomic group, representing $>75 \%$ of the relative abundance, followed by Mucoromycota (14.88\%), Mortierellomycota (2.84\%), and Basidiomycota (1.2\%); and the remaining 9 phyla were present at abundances $<1.00 \%$. At the family level, the Aspergillaceae family represented $>28 \%$ of relative abundance, followed by Nectriaceae $(25.43 \%)$, Rhizopodaceae $(14.83 \%)$, Chaetomiaceae (5.97\%), Hypocreales_fam_Incertae_sedis (3.2\%), Mortierellaceae (2.83\%), Sporormiaceae $(1.29 \%)$, and Cladosporiaceae (1.25\%); the remaining 124 families represented $<1.00 \%$. At the genus level, the most abundant was Aspergillus with $>27 \%$ of relative abundance, followed by Rhizopus $(14.83 \%)$, Fusarium (12.09\%), Acremonium (3.09\%), Mortierella (2.83\%), Chaetomium (2.75\%), Cladosporium (1.25\%), Acrophialophora (1.19\%), and Preussia (1.14\%); the remaining 248 genera had relative abundances $<1.00 \%$ (Fig. 1b shows the 20 most abundant fungal genera).

\section{Comparison of bacterial and fungal communities between plants in healthy and wilted condition}

The Venn diagrams displayed the bacterial and fungal genera shared by plants in both healthy and wilted conditions, and those exclusive to plants in either condition. In the case of bacteria, out of a total of 458 
genera found, 312 genera were shared by both conditions; and 82 and 64 genera were exclusively found in healthy and wilted conditions, respectively (detailed information on shared and exclusive bacterial genera is available in Supplementary Table 1). On the other hand, of the 257 fungal genera identified, 149 were shared by both conditions, while 75 were exclusive to the healthy condition, and 33 were unique to the wilted condition (detailed information on shared and exclusive fungal genera is available in Supplementary Table 2).

\section{a- And $\beta$-diversity}

The rarefaction curves of the bacterial and fungal samples all tended to approach the saturation plateau (Supplementary Fig. 1). The results of estimators of a-diversity did not show significant differences in the diversity and species richness of bacterial communities on the Shannon and Chao1 indexes ( $p>0.05)$; however, the species equity and dominance measured with Evenness and Simpson index showed significant differences $(p<0.05)$ (Fig. 3a). For fungi, the Shannon, Chao1, Evenness, and Simpson indexes were significantly different, evidenced by higher values in the rhizospheres of healthy plants than those of wilted ones $(p<0.05)$ (Fig. 3b).

Using principal-coordinate analysis (PCOA) we examined the variation of bacteria between healthy and wilted conditions ( $\beta$-diversity) based on weighted UniFract and Bray-Curtis distances, which explained $94.1 \%$ and $75.4 \%$ of the total observed variation, respectively, and revealed that rhizosphere bacterial communities were clustered by health conditions (ANOSIM; p <0.05) (Fig. 4a). Similarly, in the fungal communities, PCoA showed clustering according to health conditions (ANOSIM; $p<0.05$ ), which explained $99.6 \%$ (weighted UniFract) and $99.1 \%$ (Bray-Curtis) of the total observed variation (Fig. 4b).

\section{Differential Abundance Analysis}

Our analysis of the data with ALDEx2 helped us gain a better understanding of the significant changes in the abundance of microbial communities in both healthy and wilted conditions. In the bacteria, significant differences in abundance were not observed $(p>0.05)$ (Fig. 5a); however, in the fungi, a total of 17 genera had abundances that differed significantly between plant health conditions $(p<0.05)$ (Fig. 5b). The genera with significant abundance in the healthy condition were Setophaeosphaeria, Pseudogymnoascus, and Mortierella; while Rhizopus, Conocybe, Thanatephorus, Trichophaeopsis, Myceliophthora, Curvularia, Fusarium, Podospora, Cladosporium, Chaetomium, Alternaria, Acrophialophora, Coprinopsis, and Neurospora showed significant abundance in the wilted condition (Supplementary Fig. 2).

\section{Discussion}

The spread of $C$. annuum wilt and the high incidence of damage, together with the few studies of the associated microorganisms that inhabit the rhizosphere, result in great concern for all personnel involved 
in the cultivation and management of this agriculturally important crop. In the present study, we analyzed the diversity and structure of bacterial and fungal communities through 16S rRNA and ITS region amplicon-based metagenomic sequencing in rhizosphere soil of healthy as well as wilt-diseased plants under organic farming conditions. From the results, we identified a diverse community of microorganisms, of which several bacterial and fungal members were either shared by, or exclusive to, the rhizospheres of $C$. annuum plants depending on their health condition.

The taxonomic assignment confirms that rhizospheric soil of $C$. annuum is composed mainly of the Proteobacteria, Gemmatimonadetes, Actinobacteria, Bacteroidetes, and Acidobacteria phyla, the first being the most abundant. The phylum Proteobacteria has been reported in many studies for its association with the rhizosphere of plants, particularly in some studies on soil growing C. annuum [4, 34, $60,75]$. In general, at the genus level, microbial diversity was very high and homogeneous, independent of the health conditions of the plants, although genera such as Kaistobacter, Bacillus, Rubrobacter, Streptomyces, Balneimonas, Nitrospira, and Salinimicrobium were slightly more abundant than others in the rhizosphere. These genera have been reported as the most frequent in soil [21, 71]. Little information is available about the genus Kaistobacter, however, some studies have reported species of this genus as being associated with active disease suppression in the rhizosphere of tobacco plants [21, 37]. Moreover, genera including Bacillus, Rubrobacter, and Streptomyces have been reported as suppressors of rhizosphere fungi that are pathogenic to other plant species, such as Fusarium oxysporum, Rhizoctonia solani, and Verticillium dahliae $[9,12,30,56,73]$. These species were also found in this study, so future analyses should be carried out to evaluate the biological control capabilities of these bacterial members.

The Ascomycota, Mucoromycota, Mortierellomycota, and Basidiomycota were the most abundant fungal phyla, of which the first had the highest abundance. Although it is reported as a widely found phylum in the rhizosphere, only few studies have described the fungal communities associated with $C$. annuum as well as other plants belonging to the Solanaceae family $[46,58]$. The genus Aspergillus, the most abundant in this study, has been reported for its antifungal activity against Phytophthora capsici [32]; however, as that study was conducted on in vitro bioassays, caution must be exercised in drawing conclusions on biological interactions that occurunder in vivo conditions.

Studies that have evaluated the a-diversity of rhizosphere communities in agricultural crops have reported variations in the diversity, presumably because of the different factors to be considered at the time of the study (e.g., temperature, plant age, sampling season, crop rotation). Similar to the results reported in this study on bacterial richness and diversity, in plants of the Solanaceae and Piperaceae families a high bacterial diversity has been reported regardless of whether the plants were healthy or diseased [28, 35], but this was not so for evenness, which significantly declined when the crop became diseased [55]. In fungal communities, similar to what occurred in this study, a higher adiversity has been reported in healthy plants than in diseased plants[35, 62, 72]. It is worth mentioning that the agronomic practices in the plots sampled in this study were organic, so soil microorganisms had not been exposed to agrochemicals. 
In terms of community structure, several studies showed changes in the $\beta$-diversity of bacterial and fungal rhizosphere communities, caused by plant pathogen infestation [66]; our results also demonstrated that the $\beta$-diversity was segregated according to plant health condition. These differences in microbial communities may have occurred for several reasons, such as modification of soil properties due to attack and colonization of $C$. annuum plants by pathogens (e.g., $\mathrm{pH}$, nutrient solubility, $\mathrm{O}_{2}, \mathrm{CO}_{2}$, moisture), which triggered a modification of the ecological niche and resulted in the recruitment of microorganisms that exert either deleterious or beneficial effects on the plants [16].

The differential abundance test showed no significant difference in the bacterial rhizosphere regardless of plant health condition, whereas the abundance in the fungal rhizosphere differed significantly between plant conditions. In the rhizosphere of healthy plants, a significant difference was observed in the genus Mortierella, members of which have been reported as plant growth promoters, as well as antibiotic and phytohormone producers, thereby improving resistance to phytopathogens in plants of agricultural importance $[42,48,74]$. Moreover, in the rhizosphere of wilted plants, significant differences were shown in several fungal taxa, particularly in some genera that have been reported as phytopathogenic agents in various crops. This has led us to hypothesize that this increase in abundance of Thanatephorus and Fusarium species is responsible for triggering the symptomatology that affects the plants, and which subsequently allows other opportunistic pathogens (e.g., Rhizopus, Curvularia, Cladosporium, and Alternaria) to jointly infect the plant until its decay.

The genus Rhizopus was found with a higher abundance in the rhizosphere of the wilted plants, and this pathogen has been previously associated with the deterioration of crops in chili pepper $[1,19]$ and other plants, such as soybean [2], apple [61], and sugar beet [24]. Similarly, Thanatephorus, Fusarium, and Alternaria have been found to be dominant fungal genera in rhizosphere soil of chili pepper $[5,18,50,64$, 69], soybean [2], mung beans [13], and maize [43] as causal agents of wilt, root rot, leaf spot, and/or fruit and seed rot. Also, Curvularia is a plant pathogen [63]; $C$. Iunata has been reported as the causal agent of maize leaf spot [36], leaf spot disease of Clerodendrum indicum [45], and root rot of strawberry [70]. Finally, Cladosporium species have been reported as pathogenic fungi of members of the Solanaceae family such as tomato [65] and chili pepper [29], in which they cause foliar damage. Surprisingly, Phytophthora was not found in the rhizosphere of wilted or healthy chili pepper plants, while other studies carried out even in the same region have reported it as the causal organism of pepper wilt [52].

Diseases caused by soil-borne plant pathogens can be difficult to control for a variety of reasons, as many soil-borne pathogens produce persistent resistance structures that can survive in the soil for many years. Even in the absence of a susceptible host, the agricultural practices focused on reducing pathogens are either unsuitable or insufficient, as well as the selective pressure from the other microorganisms in the rhizosphere, because of competition for nutrients and essential elements [49]. However, as many other groups of microorganisms affect plant health, their pathogenic action could occur in conjunction. For example, it has been demonstrated that pathogens have the ability to secrete effector molecules that can affect the communication between plants and beneficial microorganisms, 
and that they can also recruit other microorganisms that compete against native microorganisms and help in the colonization of the host $[6,59]$.

In summary, our findings provide evidence that wilt-disease in $C$. annuum has an impact on reducing diversity and changes in the structure of bacterial and fungal rhizosphere communities. We found a complex and diverse microbial community, composed of bacterial members with a homogeneous abundance. In contrast, the abundance of some members of the fungal community was a little more heterogeneous. Several of the fungal genera we found have been reported as phytopathogens in chili pepper and other plants where a change in their individual abundance was observed, increasing significantly as the chili pepper plants wilted. In addition, further experiments should be done that isolate the pathogens found as well as the potentially beneficial microorganisms from the rhizosphere soil, to study their importance and focus on the interactions within soil microbial communities in an effort to elucidate possible biocontrol strategies. Finally, it would be interesting to explore, through metatranscriptomic analysis, the metabolic capabilities that are triggered in the rhizosphere when a plant enters a state of disease, in order to review the mechanisms of action exerted by both potentially pathogenic microorganisms and those that confer resistance to the plants.

\section{Availability of data and materials}

The datasets generated and analyzed during the current study are available in the NCBI Sequence Read Archive (SRA) repository under the BioProject with accession code PRJNA728362.

\section{Authors' contributions}

RG-E, LNM-C, and GDA-Q designed the research; LNM-C conducted the project administration; GDA-Q conducted the rhizosphere soil sampling; RG-E performed the processing and preparation of the samples; ZYM-R performed bioinformatic analysis and prepared the figures; RG-E wrote the original draft; RG-E, LNM-C, ZYM-R, CGL, and GDA-Q participated in the analysis of data, reviewed and edited the manuscript. All authors read and approved the final manuscript.

\section{Declarations}

\section{Availability of data and materials}

The datasets generated and analyzed during the current study are available in the NCBI Sequence Read Archive (SRA) repository under the BioProject with accession code PRJNA728362.

\section{Authors' contributions}

RG-E, LNM-C, and GDA-Q designed the research; LNM-C conducted the project administration; GDA-Q conducted the rhizosphere soil sampling; RG-E performed the processing and preparation of the samples; ZYM-R performed bioinformatic analysis and prepared the figures; RG-E wrote the original draft; RG-E, 
LNM-C, ZYM-R, CGL, and GDA-Q participated in the analysis of data, reviewed and edited the manuscript. All authors read and approved the final manuscript.

\section{Funding}

Not applicable

\section{Compliance with Ethical Standards}

\section{Competing interests}

The authors declare that they have no conflict of interest.

\section{Ethics Approval}

Not applicable.

\section{Consent for Publication}

Not applicable.

\section{References}

1. Ajokpaniovo H, Oyeyiola GP (2011) Rhizosphere fungi of red pepper (Capsicum frutescens). J Agric Food Sci 9:57-67. https://doi.org/10.4314/jafs.v9i2.7

2. Bai L, Cui J, Jie W, Cai B (2015) Analysis of the community compositions of rhizosphere fungi in soybeans continuous cropping fields. Microbiol Res 180:49-56. https://doi.org/10.1016/j.micres.2015.07.007

3. Barchenger DW, Lamour KH, Bosland PW (2018) Challenges and strategies for breeding resistance in Capsicum annuum to the multifarious pathogen, Phytophthora capsici. Front Plant Sci 9:1-16. https://doi.org/10.3389/fpls.2018.00628

4. Barraza A, Caamal-Chan MG, Castellanos T, Loera-Muro A (2020) Bacterial community characterization of the rhizobiome of plants belonging to Solanaceae family cultivated in desert soils. Ann Microbiol 70:34. https://doi.org/10.1186/s13213-020-01572-x

5. Bashir MR, Atiq M, Sajid M, Mohsan M, Abbas W, Alam MW, Bashair M (2018) Antifungal exploitation of fungicides against Fusarium oxysporum f. sp. capsici causing Fusarium wilt of chilli pepper in Pakistan. Environ Sci Pollut Res 25:6797-6801. https://doi.org/10.1007/s11356-017-1032-9

6. Berendsen RL, Pieterse CMJ, Bakker PAHM (2012) The rhizosphere microbiome and plant health. Trends Plant Sci 17:478-486. https://doi.org/10.1016/j.tplants.2012.04.001

7. Bolyen E, Rideout JR, Dillon MR, Bokulich NA, Abnet CC et al (2019) Reproducible, interactive, scalable and extensible microbiome data science using QIIME 2. Nat Biotechnol 37:852-857. https://doi.org/10.1038/s41587-019-0209-9 
8. Callahan BJ, McMurdie PJ, Rosen MJ, Han AW, Johnson AJA, Holmes SP (2016) DADA2: highresolution sample inference from Illumina amplicon data. Nat Methods 13:581-583. https://doi.org/10.1038/nmeth.3869

9. Cao P, Lui C, Sun P, Fu X, Wang S, Wu F, Wang X (2016) An endophytic Streptomyces sp. strain DHV32 from diseased root as a potential biocontrol agent against Verticillium dahliae and growth elicitor in tomato (Solanum lycopersicum). Antonie Leeuwenhoek 109:1573-1582. https://doi.org/10.1007/s10482-016-0758-6

10. Castrillo G, Teixeira PJPL, Paredes SH, Law TF, De Lorenzo L, Feltcher ME, Dangl JL (2017) Root microbiota drive direct integration of phosphate stress and immunity. Nature 543:513-518. https://doi.org/10.1038/nature21417

11. Castro-Rocha A, Shrestha S, Lyon B, Grimaldo-Pantoja GL, Flores-Marges JP, Valero-Galván J, Lamour K (2016) An initial assessment of genetic diversity for Phytophthora capsici in northern and central Mexico. Mycol Prog 15:15. https://doi.org/10.1007/s11557-016-1157-0

12. Chaurasia B, Pandey A, Palni LMS, Trivedi P, Kumar B, Colvin N (2005) Diffusible and volatile compounds produced by an antagonistic Bacillus subtilis strain cause structural deformations in pathogenic fungi in vitro. Microbiol Res 160:75-81. https://doi.org/10.1016/j.micres.2004.09.013

13. Dubey SC, Patel B (2012) Evaluation of fungal antagonists against Thanatephorus causing web blight of urd and mung bean cucumens. Indian Phytopathol 54:206-209

14. Dudenhöffer JH, Scheu S, Jousset A (2016) Systemic enrichment of antifungal traits in the rhizosphere microbiome after pathogen attack. J Ecol 104:1566-1575. https://doi.org/10.1111/1365-2745.12626

15. Duy M, Hoi N, Ve N, Thuc L, Trang N (2016) Influence of cellulomonas Flavigena, Azospirillum sp. and Pseudomonas sp. on rice growth and yield grown in submerged soil amended in rice straw. Recent Trends PGPR Res Sust Crop Product: 238-242

16. El-Shatnawi MKJ, Makhadmeh IM (2001) Ecophysiology of the plant-rhizosphere system. J Agron Crop Sci 187:1-9. https://doi.org/10.1046/j.1439-037X.2001.00498.x

17. Erwin DC, Ribeiro OK (1996) Phytophthora diseases worldwide. The American Phytopathological Society, St. Paul

18. Fajardo-Rebollar E, Estrada K, Grande R, Ek Ramos MJ, Ruiz-Vargas G, Villegas-Torres OG, Juárez A, Sánchez-Flores A, Camino CD (2021) Bacterial and fungal microbiome profiling in chilhuacle negro chili (Capsicum annuum L.) associated with fruit rot disease. Plant Dis. https://doi.org/10.1094/PDIS-09-20-2098-RE

19. Fatimoh A, Akinjide A, Adekunle O, Olowolaju E (2018) Isolation and identification of rot fungi on post-harvest of pepper (Capsicum annuum L.) Fruits. AASCIT J Biol 3:24-29

20. Fernandes AD, Macklaim JM, Linn TG, Reid G, Gloor GB (2013) ANOVA-Like Differential Expression (ALDEx) analysis for mixed population RNA-sEq. PLoS ONE 8(7):e67019. https://doi.org/10.1371/journal.pone.0067019 
21. Gkarmiri K, Mahmood S, Ekblad A, Alström S, Högberg N, Finlay R (2017) Identifying the active microbiome associated with roots and rhizosphere soil of oilseed rape. Appl Environ Microbiol 83:114. https://doi.org/10.1128/AEM.01938-17

22. Guigón-López C, González-González PA (2001) Estudio regional de las enfermedades del chile (Capsicum annuum, L.) y su comportamiento temporal en el sur de Chihuahua, México. Rev Mex Fitopatol 19:49-56

23. Guigón-López C, Guerrero-Prieto V, Vargas-Albores F, Carvajal-Millán E, Ávila-Quezada GD, Bravo-Luna L, Lorito M (2010) Identificación molecular de cepas nativas de Trichoderma spp. su tasa de crecimiento in vitro y antagonismo contra hongos fitopatógenos. Rev Mex Fitopatol 28:87-96

24. Hanson LE (2010) Interaction of Rhizoctonia solani and Rhizopus stolonifer causing root rot of sugar beet. Plant Dis 94:504-509. https://doi.org/10.1094/PDIS-94-5-0504

25. Harman GE, Uphoff N (2019) Symbiotic root-endophytic soil microbes improve crop productivity and provide environmental benefits. Scientifica 2019:1-25. https://doi.org/10.1155/2019/9106395

26. Hassan MK, Mclnroy JA, Jones J, Shantharaj D, Liles MR, Kloepper JW (2019) Pectin-rich amendment enhances soybean growth promotion and nodulation mediated by Bacillus velezensis strains. Plants 8:120. https://doi.org/10.3390/plants8050120

27. Hossain M, Ran C, Liu K, Ryu CM, Rasmussen-Ivey C, Williams M, Hassan M, Choi SK, Jeong H, Newman $\mathrm{M}$ et al (2015) Deciphering the conserved genetic loci implicated in plant disease control through comparative genomics of Bacillus amyloliquefaciens subsp. plantarum. Front Plant Sci 6:631. https://doi.org/10.3389/fpls.2015.00631

28. Hu Q, Tan L, Gu S, Xiao Y, Xiong X, Zeng W, Feng K, Wei Z, Deng Y (2020) Network analysis infers the wilt pathogen invasion associated with non-detrimental bacteria. Npj Biofilms Microbiomes 6:1-8. https://doi.org/10.1038/s41522-020-0117-2

29. Huang XY, Liu ZH, Hu JX, Wang SW, Zou Y, Zhang S, Yang H (2012) First report of a leaf spot on pepper caused by Cladosporium oxysporum in China. Plant Dis 96:1072. https://doi.org/10.1094/PDIS-04-12-0323-PDN

30. Islam MR, Jeong YT, Lee YS, Song CH (2012) Isolation and identification of antifungal compounds from Bacillus subtilis $C 9$ inhibiting the growth of plant pathogenic fungi. Mycobiology 40:59-65. https://doi.org/10.5941/MYC0.2012.40.1.059

31. Jiang H, Zhang L, Zhang JZ, Ojaghian MR, Hyde KD (2016) Antagonistic interaction between Trichoderma asperellum and Phytophthora capsici in vitro. J Zhejiang Univ-Sci B 17:271-281. https://doi.org/10.1631/jzus.B1500243

32. Kang S, Kim S (2004) New antifungal activity of penicillic acid against Phytophthora species. Biotechnol Lett 26:695-698. https://doi.org/10.1023/B:BILE.0000024090.96693.a4

33. Katoh K, Standley DM (2013) MAFFT multiple sequence alignment software version 7: improvements in performance and usability. Mol Biol Evol 30:772-780. https://doi.org/10.1093/molbev/mst010 
34. Li H, Cai X, Gong J, Xu T, Ding G, Li J (2019) Long-term organic farming manipulated rhizospheric microbiome and Bacillus antagonism against pepper blight (Phytophthora capsici). Front Microbiol 10:1-12. https://doi.org/10.3389/fmicb.2019.00342

35. Li Z, Zu C, Wang C, Yang J, Yu H, Wu H (2016) Different responses of rhizosphere and nonrhizosphere soil microbial communities to consecutive Piper nigrum L. monoculture. Sci Rep 6:1-8. https://doi.org/10.1038/srep35825

36. Liu T, Liu L, Jiang X, Huang X, Chen J (2009) A new furanoid toxin produced by Curvularia lunata, the causal agent of maize Curvularia leaf spot. Can J Plant Pathol 31:22-27. https://doi.org/10.1080/07060660909507568

37. Liu X, Zhang S, Jiang Q, Bai Y, Shen G, Li S, Ding W (2016) Using community analysis to explore bacterial indicators for disease suppression of tobacco bacterial wilt. Sci Rep 6:36773. https://doi.org/10.1038/srep36773

38. Lombardi N, Vitale S, Turrà D, Reverberi M, Fanelli C, Vinale F, Lorito M (2018) Root exudates of stressed plants stimulate and attract Trichoderma soil fungi. Mol Plant Microbe Interact 31:982-994. https://doi.org/10.1094/MPMI-12-17-0310-R

39. Madrid-Delgado G, Orozco-Miranda M, Cruz-Osorio M, Hernández-Rodríguez OA, Rodríguez-Heredia R, Roa-Huerta M, Avila-Quezada GD (2021) Pathways of phosphorus absorption and early signaling between the mycorrhizal fungi and plants. Phyton-Int J Exp Bot 90(3). https://doi.org/10.32604/phyton.2021.016174

40. Magoc T, Salzberg SL (2011) FLASH: fast length adjustment of short reads to improve genome assemblies. Bioinformatics 27:2957-2963. https://doi.org/10.1093/bioinformatics/btr507

41. Manzoni S, Schimel JP, Porporato A (2012) Responses of soil microbial communities to water stress: results from a meta-analysis. Ecology 93:930-938. https://doi.org/10.1890/11-0026.1

42. Mares-Ponce de León Y, Muñoz-Castellanos LN, Ruiz-Cisneros MF, Pérez-Corral DA, Ornelas-Paz JJ, Acosta-Muñiz CH, Berlanga-Reyes DI, Rios-Velasco C (2018) Morphological and molecular identification of Mortierella species associated to rhizosphere of apple trees with symptoms of root diseases. Rev Mex Fitopatol 36:184-195. https://doi.org/10.18781/R.MEX.FIT.1710-2

43. Medina-de la Rosa G, López-Reyes L, Carcaño-Montiel MG, López-Olguín JF, Hernández-Espinosa M, Rivera-Tapia JA (2016) Rhizosphere bacteria of maize with chitinolytic activity and its potential in the control of phytopathogenic fungi. Arch Phytopathol Plant Protect 49:310-321. https://doi.org/10.1080/03235408.2016.1201345

44. Mendes R, Garbeva P, Raaijmakers JM (2013) The rhizosphere microbiome: Significance of plant beneficial, plant pathogenic, and human pathogenic microorganisms. FEMS Microbiol Rev 37:634663. https://doi.org/10.1111/1574-6976.12028

45. Mukherjee A, Bandhyopadhyay A, Dutta S (2013) New report of leaf spot disease of Clerodendrum indicum caused by Curvularia lunata. Int J Pharma Bio Sci 3:659-668

46. Naziya B, Murali M, Amruthesh KN (2019) Plant Growth-Promoting Fungi (PGPF) instigate plant growth and induce disease resistance in Capsicum annuum L. upon infection with Colletotrichum 
capsici. (Syd.) Butler Bisby Biomolecules 10:41. https://doi.org/10.3390/biom10010041

47. Ordóñez-Beltrán V, Orduño-Cruz N, Ríos-Velasco C, Jacobo-Cuellar JL, Hernández-Domínguez C, Acosta-Muñiz $\mathrm{CH}$ (2020) Characterization of rhizobacteria associated with Vitis vinifera and its interaction in vitro with entomopathogenic fungi. Eurasian Soil Sci 53:1469-1479

48. Ozimek E, Jaroszuk-Ściseł J, Bohacz J, Korniłłowicz-Kowalska T, Tyśkiewicz R, Słomka A, Nowak A, Hanaka A (2018) Synthesis of indoleacetic acid, gibberellic acid and ACC-deaminase by Mortierella strains promote winter wheat seedlings growth under different conditions. Int J Mol Sci 19:3218. https://doi.org/10.3390/ijms19103218

49. Pascale A, Proietti S, Pantelides IS, Stringlis IA (2020) Modulation of the root microbiome by plant molecules: The basis for targeted disease suppression and plant growth promotion. Front Plant Sci 10:1-23. https://doi.org/10.3389/fpls.2019.01741

50. Pérez-Hernández A, Serrano-Alonso Y, Aguilar-Pérez MI, Gómez-Uroz R, Gómez-Vázquez J (2014) Damping-off and root rot of pepper caused by Fusarium oxysporum in Almería province, Spain. Plant Dis 98:1159-1159. https://doi.org/10.1094/PDIS-02-14-0212-PDN

51. Price MN, Dehal PS, Arkin AP (2010) FastTree 2-approximately maximum-likelihood trees for large alignments. PLoS ONE 5:e9490. https://doi.org/10.1371/journal.pone.0009490

52. Sánchez-Chávez E, Silva-Rojas HV, Leyva-Mir G, Villarreal-Guerrero F, Jiménez-Castro JA, MolinaGayosso E, Ávila-Quezada GD (2017) An effective strategy to reduce the incidence of Phytophthora root and crown rot in bell pepper. Interciencia 42:229-235

53. Sánchez-Gurrola C, Gómez-Dorantes N, Rodríguez-Alvarado G, Fernández-Pavía SP, Ávila-Quezada G (2019) Variabilidad morfológica y sensibilidad de Phytophthora capsici causando marchitez en chile pimiento morrón en Chihuahua, México. Rev Mex Fitopatol 37:65-71.

https://doi.org/10.18781/R.MEX.FIT.1904-4

54. Sanogo S, Carpenter J (2006) Incidence of Phytophthora blight and Verticillium wilt within chile pepper fields in New Mexico. Plant Dis 90:291-296. https://doi.org/10.1094/PD-90-0291

55. She S, Niu J, Zhang C, Xiao Y, Chen W, Dai L, Liu X, Yin H (2017) Significant relationship between soil bacterial community structure and incidence of bacterial wilt disease under continuous cropping system. Arch Microbiol 199:267-275. https://doi.org/10.1007/s00203-016-1301-x

56. Siegel-Hertz K, Edel-Hermann V, Chapelle E, Terrat S, Raaijmakers JM, Steinberg C (2018) Comparative microbiome analysis of a Fusarium wilt suppressive soil and a Fusarium wilt conducive soil from the Châteaurenard region. Front Microbiol 9:568.

https://doi.org/10.3389/fmicb.2018.00568

57. Silva-Rojas HV, Fernández-Pavia SP, Góngora-Canul C, Macías-López BC, Ávila-Quezada GD (2009) Distribución espacio temporal de la marchitez del chile (Capsicum annuum L.) en Chihuahua e identificación del agente causal Phytophthora capsici Leo. Rev Mex Fitopatol 27:134-147. http://www.scielo.org.mx/pdf/rmfi/v27n2/v27n2a6.pdf

58. Singh AK, Singh M, Dubey SK (2014) Rhizospheric fungal community structure of a Bt brinjal and a near isogenic variety. J Appl Microbiol 117:750-765. https://doi.org/10.1111/jam.12549 
59. Snelders NC, Kettles GJ, Rudd JJ, Thomma BPHJ (2018) Plant pathogen effector proteins as manipulators of host microbiomes? Mol Plant Pathol 19:257-259.

https://doi.org/10.1111/mpp.12628

60. Song Y, Li X, Yao S, Yang X, Jiang X (2020) Correlations between soil metabolomics and bacterial community structures in the pepper rhizosphere under plastic greenhouse cultivation. Sci Total Environ 728:138439. https://doi.org/10.1016/j.scitotenv.2020.138439

61. Sun J, Zhang Q, Li X, Zhou B, Wei Q (2017) Apple replant disorder of Pingyitiancha Rootstock is closely associated with rhizosphere fungal community development. J Phytopathol 165:162-173. https://doi.org/10.1111/jph.12547

62. Tan Y, Cui Y, Li H, Kuang A, Li X, Wei Y, Ji X (2017) Rhizospheric soil and root endogenous fungal diversity and composition in response to continuous Panax notoginseng cropping practices. Microbiol Res 194:10-19. https://doi.org/10.1016/j.micres.2016.09.009

63. Tan YP, Crous PW, Shivas RG (2018) Cryptic species of Curvularia in the culture collection of the Queensland Plant Pathology Herbarium. MycoKeys 35:1-25.

https://doi.org/10.3897/mycokeys.35.25665

64. Thakur S, Paul YS (2013) Antifungal activity of cow urine distillates of local botanicals against major pathogens of bell pepper. Afr J Agric Res 8:6171-6177

65. Thomma BPHJ, Van Esse HP, Crous PW, De Wit PJGM (2005) Cladosporium fulvum (syn. Passalora fulva), a highly specialized plant pathogen as a model for functional studies on plant pathogenic Mycosphaerellaceae. Mol Plant Pathol 6:379-393. https://doi.org/10.1111/j.1364-

3703.2005.00292.x

66. Tsang KSW, Cheung MK, Lam RYC, Kwan HS (2020) A preliminary examination of the bacterial, archaeal, and fungal rhizosphere microbiome in healthy and Phellinus noxius -infected trees. MicrobiologyOpen 9:e1115. https://doi.org/10.1002/mbo3.1115

67. Vásquez-López A, Tlapal-Bolaños B, Yañez-Morales MDJ, Pérez-Pacheco R, Quintos-Escalante M (2009) Etiology of pepper wilt disease of 'chile de agua' (Capsicum annuum L.) in Oaxaca, México. Rev Fitotec Mex 32:127-134

68. Velarde-Félix S, Garzón-Tiznado JA, Hernández-Verdugo S, López-Orona CA, Retes-Manjarrez JE (2018) Occurrence of Fusarium oxysporum causing wilt on pepper in Mexico. Can J Plant Pathol 40:238-247. https://doi.org/10.1080/07060661.2017.1420693

69. Velásquez-Valle R, Medina-Aguilar MM, Luna-Ruiz JDJ (2001) Sintomatología y géneros de patógenos asociados con las pudriciones de la raíz del chile (Capsicum annuum L.) en el NorteCentro de México. Rev Mex Fitopatol 19:175-181

70. Verma VS, Gupta VK (2010) First Report of Curvularia lunata causing root rot of strawberry in India. Plant Dis 94:477-477. https://doi.org/10.1094/PDIS-94-4-0477C

71. Wu J, Jiao Z, Zhou J, Guo F, Ding Z, Qiu Z (2017) Analysis of bacterial communities in rhizosphere soil of continuously cropped healthy and diseased konjac. World J Microbiol Biotechnol 33:134. https://doi.org/10.1007/s11274-017-2287-5

Page 15/21 
72. Yang J, Wei S, Su D, Zhang Z, Chen S, Luo Z, Cui X (2020) Comparison of the rhizosphere soil microbial community structure and diversity between powdery mildew-infected and noninfected strawberry plants in a greenhouse by high-throughput sequencing technology. Curr Microbiol 77:1724-1736. https://doi.org/10.1007/s00284-020-01948-x

73. Yao X, Huang K, Zhao S, Cheng Q, Zhang S, Yang L, Zhang Y (2020) Identification and verification of rhizosphere indicator microorganisms in tobacco root rot. Agron J 113:1480-1491. https://doi.org/10.1002/agj2.20547

74. Zhang K, Bonito G, Hsu CM, Hameed K, Vilgalys R, Liao HL (2020) Mortierella elongata increases plant biomass among non-leguminous crop species. Agronomy 10:754. https://doi.org/10.3390/agronomy 10050754

75. Zhang LN, Wang DC, Hu Q, Dai XQ, Xie YS, Li Q, Liu HM, Guo JH (2019) Consortium of plant growthpromoting rhizobacteria strains suppresses sweet pepper disease by altering the rhizosphere microbiota. Front Microbiol 10:1-10. https://doi.org/10.3389/fmicb.2019.01668

\section{Figures}


(a)

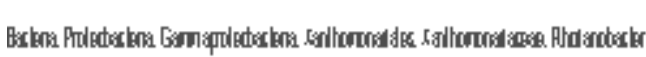

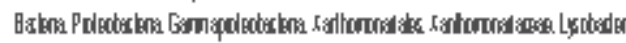

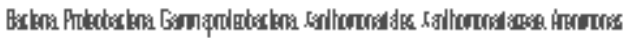

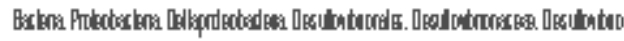

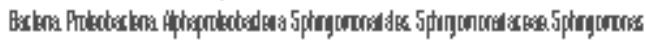

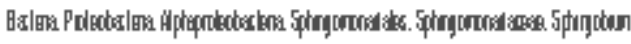

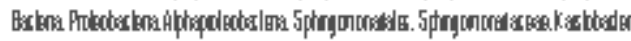

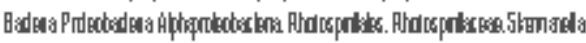

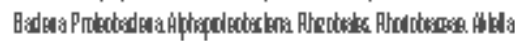

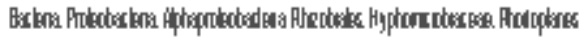

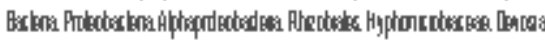

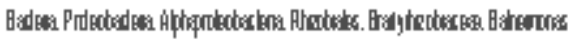

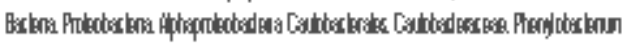

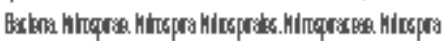

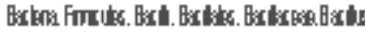

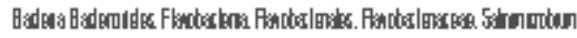

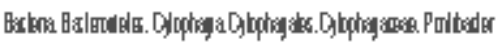

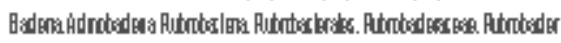

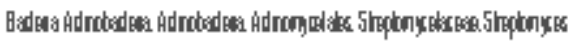

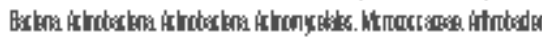
Renster

(b)

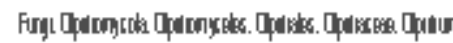

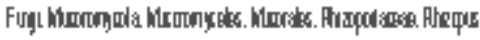

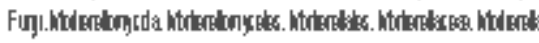

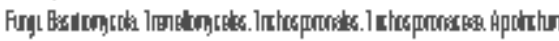

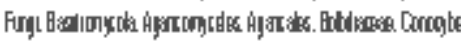

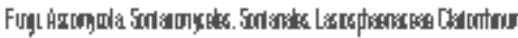

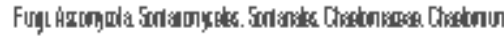

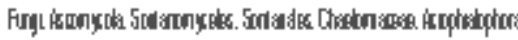

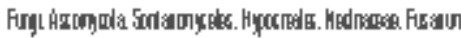

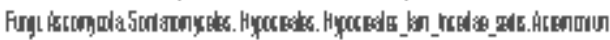

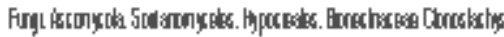

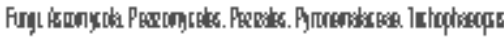

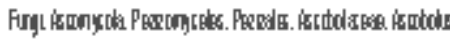

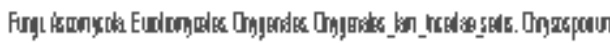

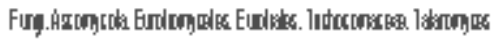

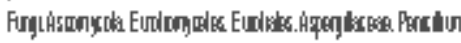

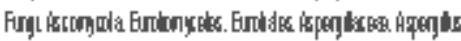

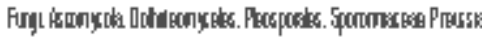

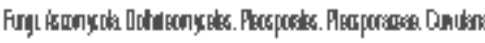

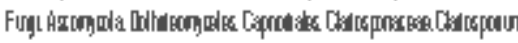
Aenarier

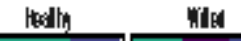
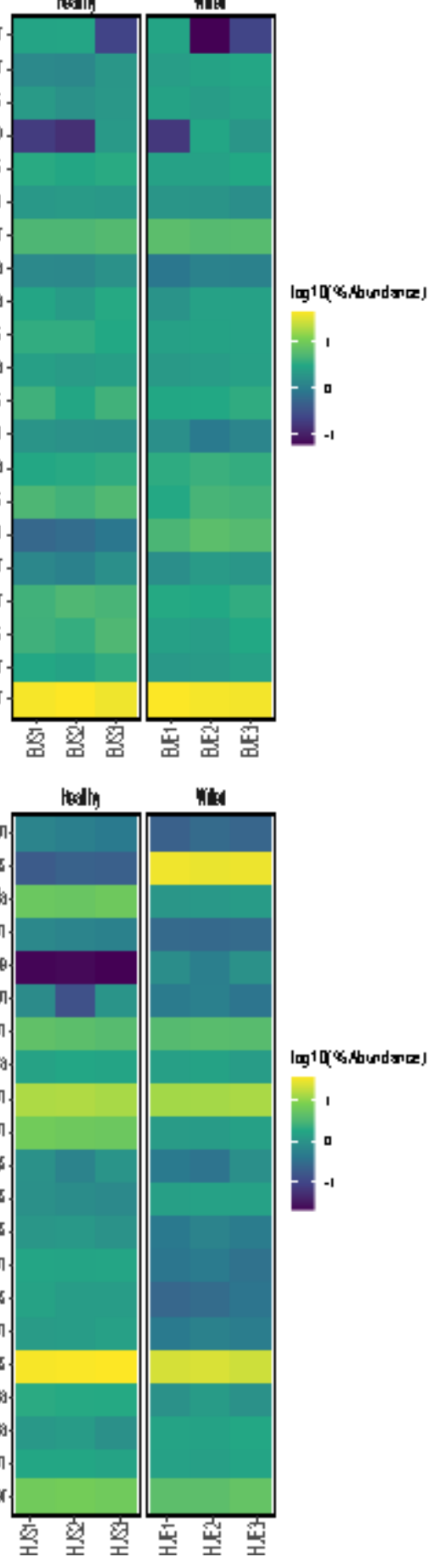

\section{Figure 1}

Heat map depicting bacterial (a) and fungal (b) diversity based on the relative abundances. 
(a)

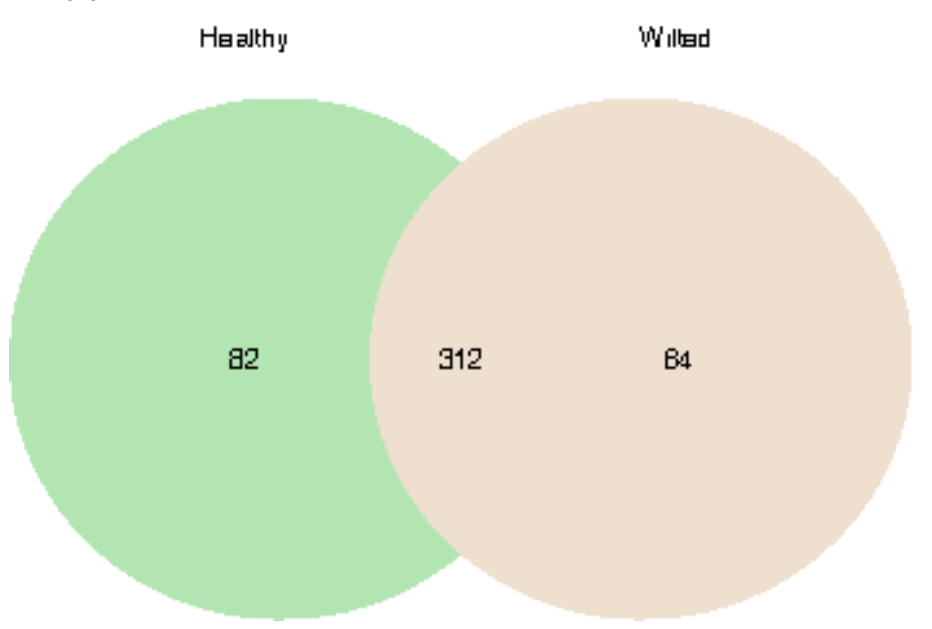

(b)

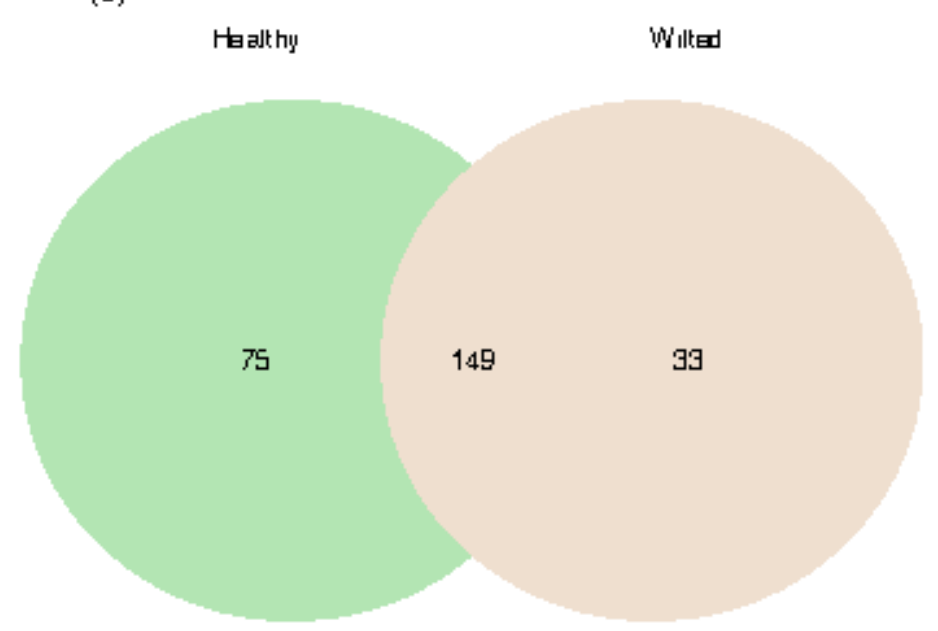

\section{Figure 2}

Venn diagrams showing the distribution of (a) bacterial and (b) fungal genera shared by the rhizospheres of both healthy and wilted C. annuum L. plants, and those exclusive to either condition. 
(a)
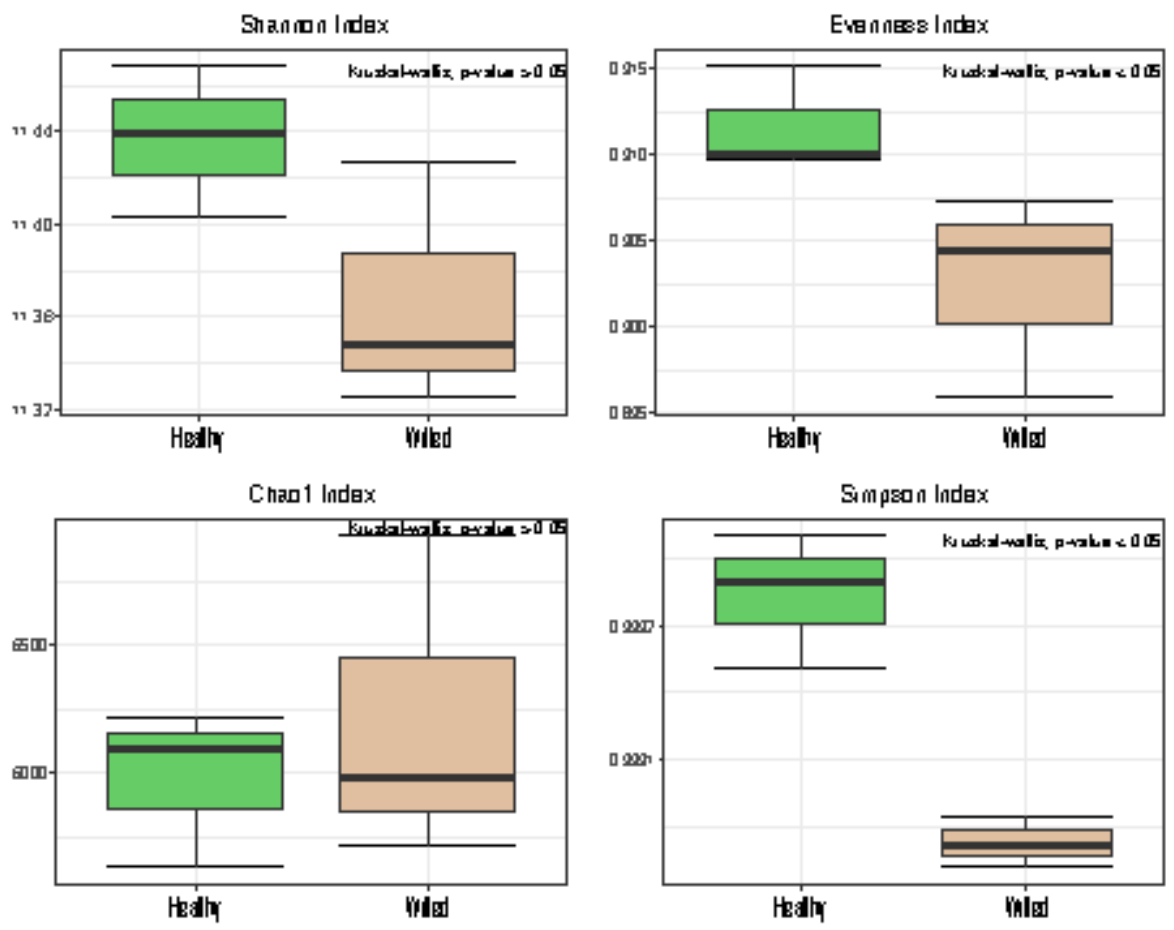

(b)
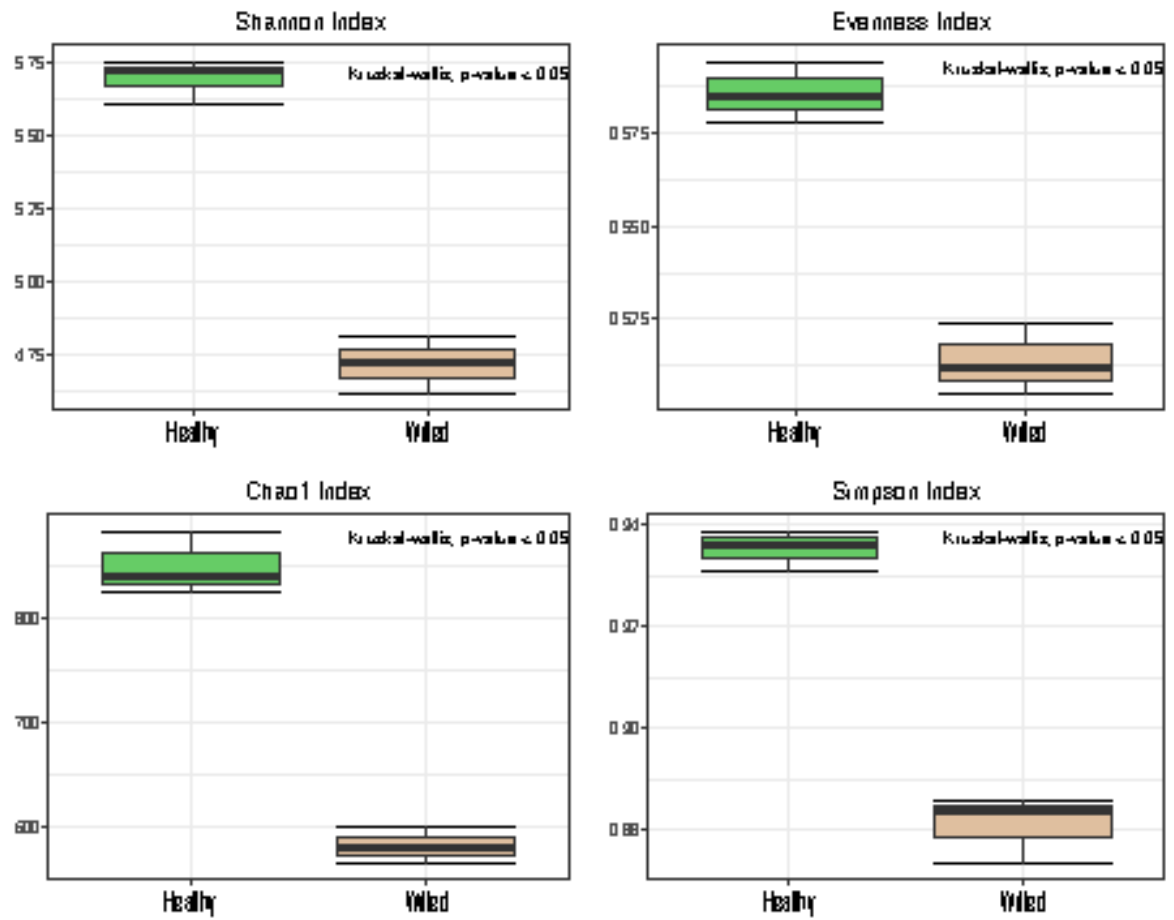

Figure 3

a-diversity index of bacterial (a) and fungal (b) communities. 
(a)

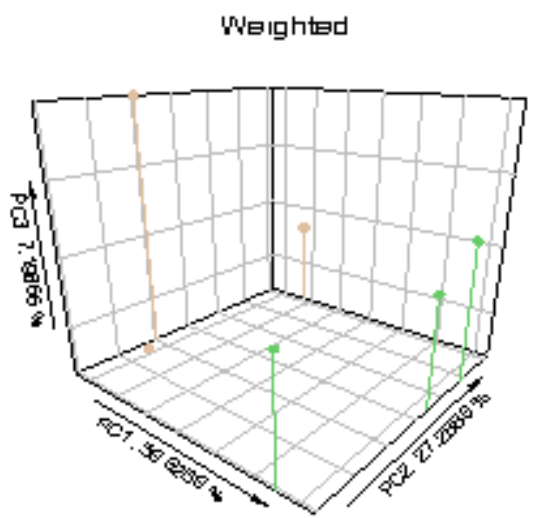

(b)

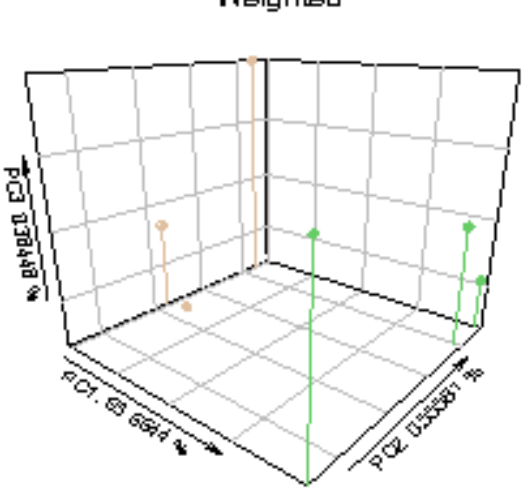

Eacterla

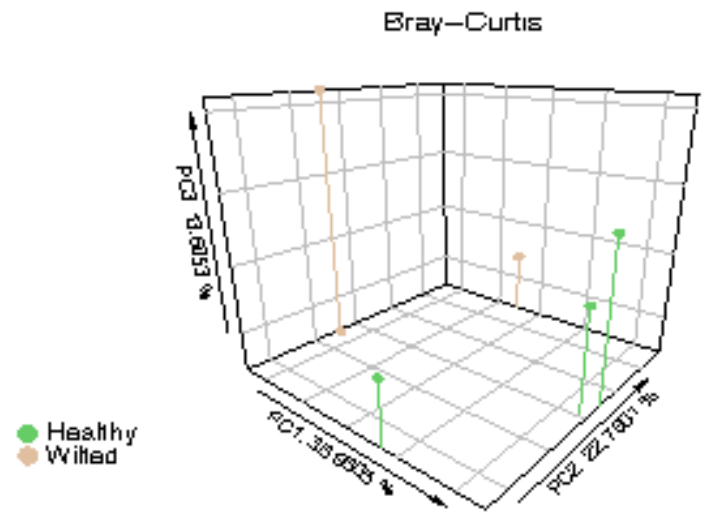

Fung।

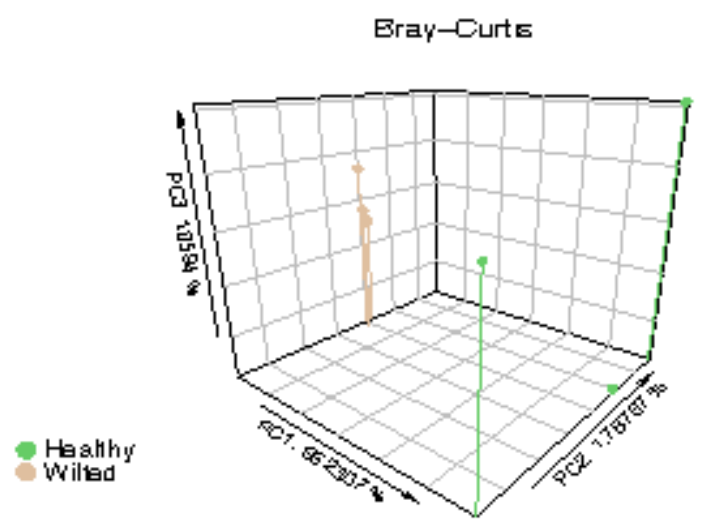

Figure 4

PCoAs built with weighted unifrac and pairwise Bray-Curtis dissimilarity matrices of bacterial (a) and fungal (b) communities. 
(a)

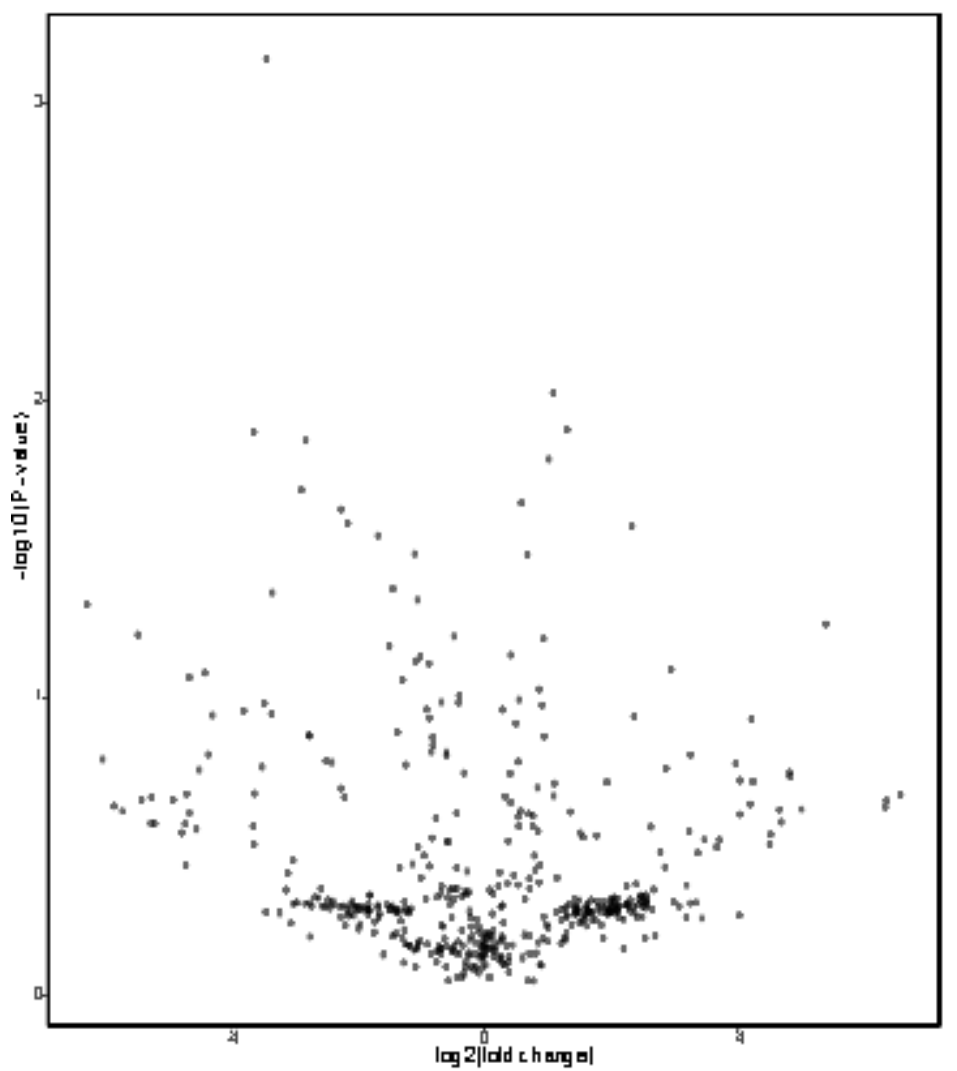

(b)

Furgi

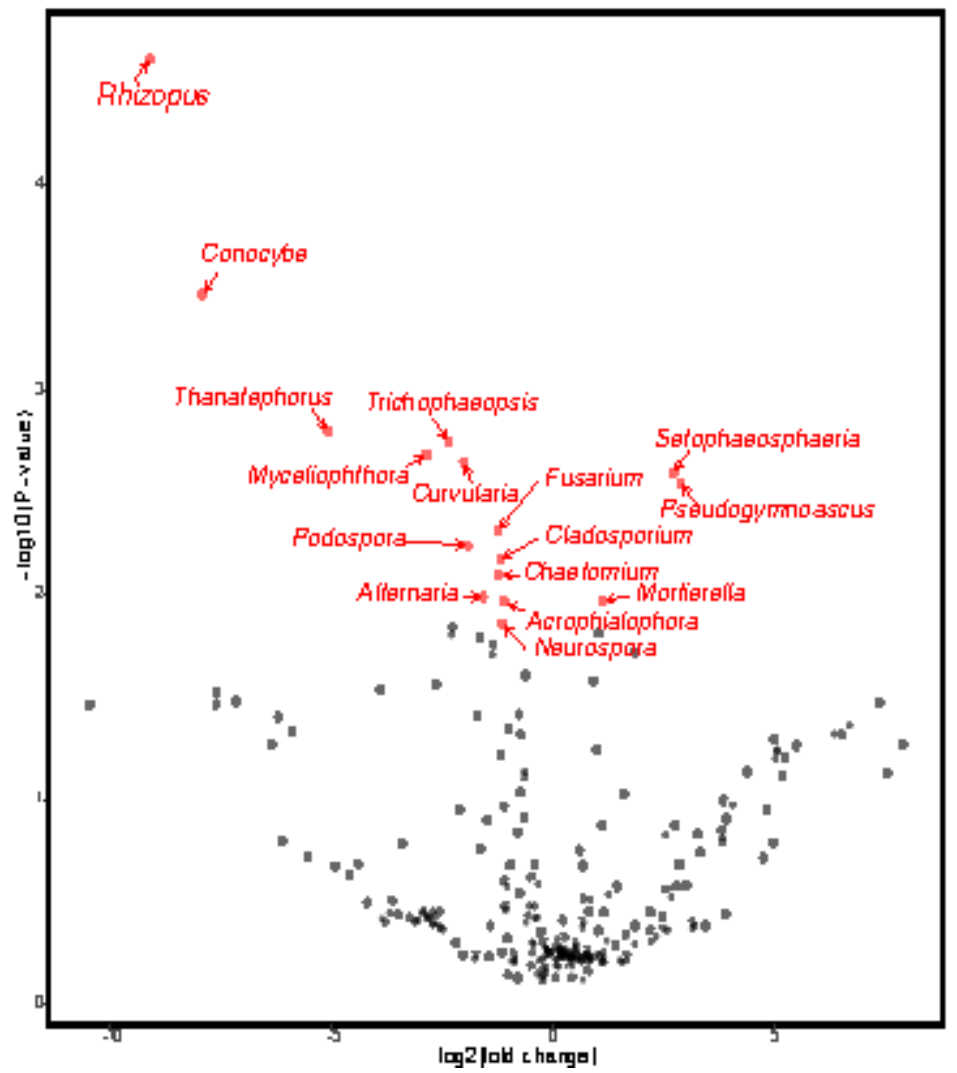

Figure 5

Volcano plot of differential abundance analysis of bacterial (a) and fungal (b) communities. Dots in red represent genera with differentially significant abundance.

\section{Supplementary Files}

This is a list of supplementary files associated with this preprint. Click to download.

- SupplementaryFiguresMECO.docx

- SupplementaryTable1.xls

- SupplementaryTable2.xls 